\title{
Unpacking Writing Needs of Nepalese University Students
}

\author{
Gopal Prasad Pandey, Ph.D. \\ Tribhuvan University, Kathmandu, Nepal \\ gpandeytu@gmail.com
}

DOI: http://doi.org/10.36892/ijlls.v2i2.275

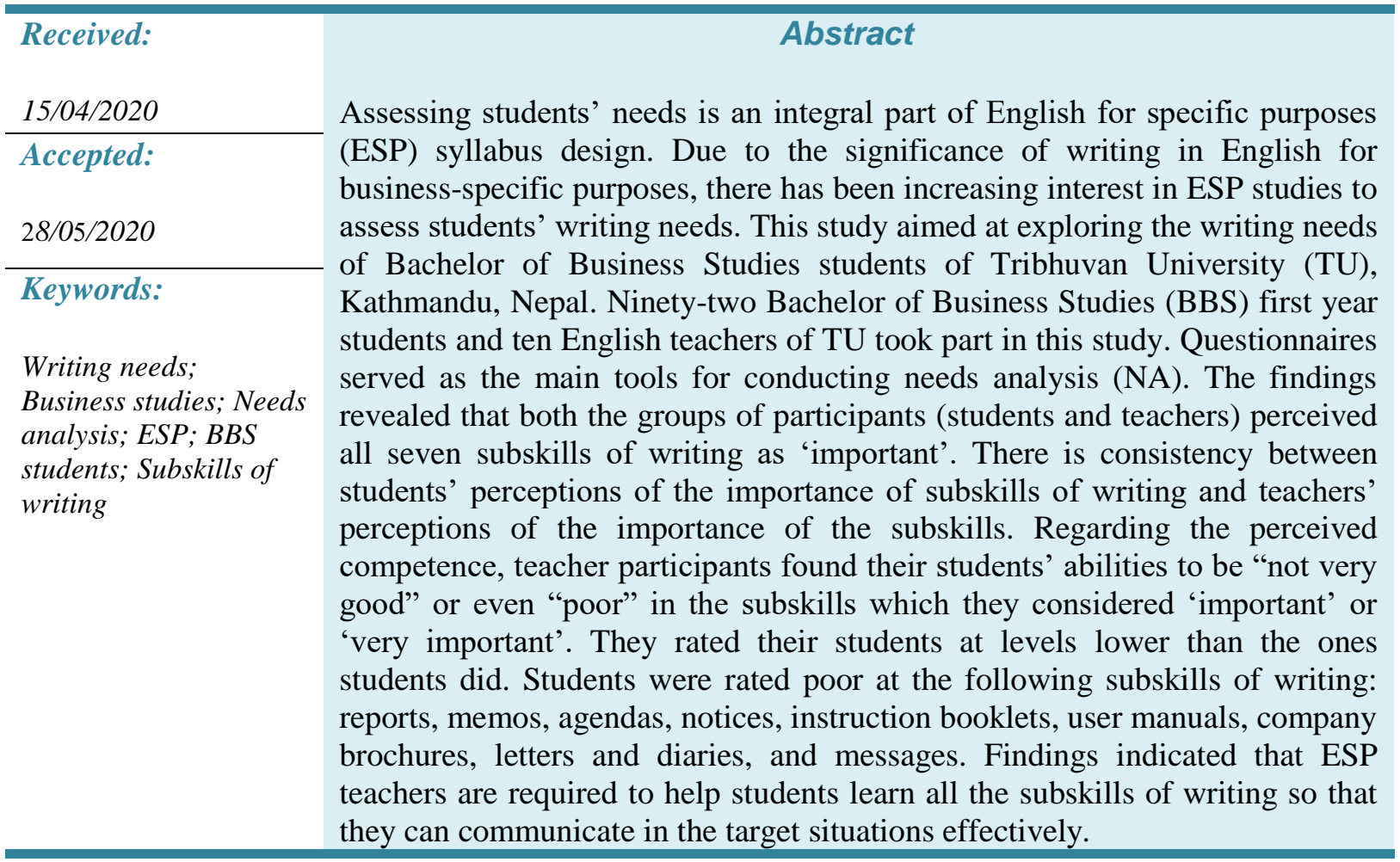

\section{INTRODUCTION}

Writing is one of the basic skills of language along with listening, speaking, and reading. Complex social activities like educating students, keeping records, engaging with customers, selling products, demonstrating learning, and disseminating ideas largely depend on it (Hyland, 2013). It is the central activity of academia. Written communication has become one of the indicators that show the level of development in modern societies. In this regard, the development of writing skills in students is extremely important as it is one of the media through which they can express their thoughts and feelings to fulfill their purposes. Writing emails, commercial letters, reports, memos, notes, and minutes of meetings are the part of modern academic and corporate life. Thus, writing is a key feature of students' life. Their success is measured by their writing. With the continued dominance and influence of English as an international language, students need to consolidate their learning and demonstrate their ability in writing. Writing is considered to be a highly important skill for students of higher education and English for specific purposes courses.

Writing is generally regarded as a difficult skill and a complex task (Graham, Harris, \& Mason, 2005; Chowdhury, 2020). The difficulty lies not in generating and organizing ideas, but also in translating these ideas into readable texts. The skills involved in writing are highly complex. It is a difficult skill for native and non-native speakers alike because writers should 
balance multiple issues, such as content, organization, purpose, audience, vocabulary, punctuation, spelling, and mechanics. Obviously, the non-native students, the students of English as a foreign language in particular find writing is more difficult than native learners of students do. Foreign language learners have to pay attention to higher-level skills of planning and organizing as well as lower-level skills of spelling, punctuation, etc.

Students also have to be aware of the conventions of discipline-specific writing so that they can communicate with friends and scholars in their fields. The importance of disciplinespecific writing can be expressed as below:

Writing in the Disciplines (WID) is primarily a college-level initiative, based on the belief that each discipline has its own conventions of language use and style and that these conventions must be taught to students so that they might successfully participate in academic discourse (OWL, 2003, p. 1).

Hyland (2002) opines that "specificity is an essential task of EAP/ESP writing" and warns against the adoption of an 'autonomous' view of literacy, which "misleads learners into believing that they simply have to master a set of rules which can be transferred across fields" (p. 392). Song (2000) further highlights the importance of writing stating that cooperation is even more significant, effectively achieved through 'linked language and discipline-specific content courses. This paper looks into the writing needs and problems of BBS students at Tribhuvan University, Nepal.

\section{LITERATURE REVIEW}

This review section forms the theoretical basis for the study which delineates the significance of writing in business studies, trends in ESP, and needs analysis in the ESP approach to teaching.

\section{Significance of Writing in Business Studies}

The significance of writing, especially genres such as e-mail, advertisements, letters, meetings, and reports which require proficiency in written communication cannot be overestimated (Bacha, 2003; Campbell, 2002; Nickerson, 2005, as cited in Bacha \& Bahous, 2008). Writing skills are considered to be important in the in university context as students' success is measured by their success in writing. Campbell $(2002$, p. 1) states:

Motivating business ... students in a writing class is often difficult. . . Many students do not even think writing is that important - at least not in the 'real' or 'content' courses such as economics and accounting. . . or do not see clearly how it relates to their degree or future career.

Schott Karr (2001, p. 1) also stresses the importance of writing for the students' careers. He states "Business writing will continue to be valued by recruiters and hiring professionals, who believe a person's ability to write well can help him or her move up the corporate ladder.' Bernhardt (1985) carried out a research on 'writing' with undergraduates at the College of Liberal Arts Council of Southern Illinois University, Carbondale. He concluded that both students and faculty give importance to writing, especially the different genres such as descriptions, letters, case studies, research reports. Other studies related to writing show that teachers need to help the students acquire learning strategies and prepare them for the job market with practice through e-mail and the internet (Schott Karr, 2001), letters, case studies, research reports, and interactive business reports.

\section{English for Specific Purposes as an Approach to Teaching}

The study of languages for specific purposes features an extended and sundry history (Strevens, 1977). In recent years, ESP studies have gained currency in the field of ELT due to the tremendous developments in science, technology, and trade. It has become a major development focus in areas of what we exactly call communicative syllabus design and 
material production. "As TESOL enters its second quarter- century, the demand for English for specific purposes (e.g., English for Science and Technology, English for Business) continues to increase and expand throughout the world" (Johns \& Dudley-Evans, 1991, p. 297). ESP thus has become a cornerstone of syllabus design and materials production.

Research in ESP teaching and learning originated in the UK in the 1960s and has been growing exponentially ever since. Today it is one of the main areas of EFL teaching, which is mirrored in an increasing demand for ESP courses in a wide variety of specialised subject areas. Moreover, ESP has seen a growing number of journals of which the most important is the journal of English for Specific Purposes founded in 1980 (and later renamed ESP Journal), and the most recent is the Journal of Englishfor Academic Purposes. The major pioneers in this field are: John Swales, Larry Selinker, John Lackstrom, Tom Hutchinson and Alan Waters, Tony Dudley Evans, Louis Trimble, and Henry Widdowson, among others (Raisanen \& Fortanet-Gomez, 2008).

Since the 1960s, ESP has become a vital and innovative activity within the TESL or TEFL movement. English teachers now around the globe are called on to teach English in job-related or career settings. ESP approach is motivating and effective if English students are adults with a common professional interest. Needs analysis (NA) is always at the heart of the ESP approach to language teaching. That is, NA has long been the cornerstone of ESP course design, materials development, and program implementation and assessment. For Munby (1978), "ESP courses are those where the syllabus and materials are determined in all essentials by the prior analysis of the communication needs of the learner" (p. 2). Hutchinson and Waters (1987) define ESP as "an approach to language teaching in which all decisions as to content and method are based on the learner's reason for learning" (p. 19). They see ESP as an approach rather than a product, by which they mean that ESP does not involve a particular kind of language, teaching material, or methodology. They argue that the foundation of ESP is the simple question: Why does this learner need to learn a foreign language? The answer to this question relates to the learners, the language required and the learner context, and thus establishes the primacy of the need in ESP. Strevens (1988) opines: ESP is a particular case of the general category of special purposes language teaching. He makes a distinction between four absolute characteristics, and two variable characteristics. Robinson (1991) also accepts the primacy of needs analysis in defining ESP. For her "ESP is a goal-oriented language teaching and ESP courses develop from a needs analysis which aims to specify as closely as possible what exactly it is that have to do through the medium of English" (Robinson, 1991, p. 2). ESP course has its own range of emphases and priorities. ESP is designed to meet the specific needs of the learner and it may be related to or designed for specific disciplines.

Dudley-Evans and St. John (2003), in a more recent study, have modified Strevens' definition and exposit their revised view on the essence of ESP from the following two perspectives: Absolute characteristics and Variable Characteristics.

\section{Needs Analysis in ESP Studies}

NA is of vital importance in the process of designing and carrying out any language course, whether it be English for Specific Purposes (ESP) or general English course, and its centrality has been acknowledged by several scholars and authors (Richterich \& Chancerel, 1977; Munby, 1978; Chambers, 1980; Hutchinson \& Waters, 1987; Berwick, 1989; Brindley, 1989; Johns, 1990; Robinson, 1991; West, 1994, 1997; Seedhouse, 1995; Jordan, 1997; Dudley-Evans \& St. John, 2003; Richards, 2001; Finney, 2002; Grier, 2005; Long, 2005).

NA has long been paramount for ESP course design, materials development, and program implementation and assessment. Throughout its history, ESP practitioners have been preoccupied with learner needs, with identifying learner wants and purposes as integral and 
obligatory elements in materialsdesign (Johns, 1990 \& Robinson, 1991). Much has been written about the importance of devoting time to data collection before courses get underway. ESP course is usually tailor-made. It caters for the needs of learners in specific disciplines other than the arts and languages. The main purpose of learning the language is to communicate within a specific academic, occupational or professional domain. In the last few decades, ESP course designers have been advocating the uses of various approaches and modes, to collect data useful for the particular group of learners, such as target situation analysis, deficiency analysis, means analysis, genre analysis and language audits (DudleyEvans \& St. John, 2003; West, 1994, 1997).

\section{The Present Study}

\section{Research Questions}

The study aimed at conducting a needs analysis of Nepalese BBS students to identify ESP writing needs and problems. The study addressed the following questions:

a) What subskills of writing do BBS students need to develop in order to function effectively in the target situation?

b) How do students and teachers perceive writing?

c) To what extent do student-participants' opinions match with those of teachers in terms of perceived importance and competence?

\section{METHODOLOGY}

\section{Research Design}

The study adopts a survey design approach. The survey design systematically gathers information from respondents for the purpose of understanding and/or predicting some aspects of the behaviour of the population of interest. According to Gay, Mills and Airasian (2017, p. 192), "Survey research involves collecting data to test hypotheses or to answer questions about people's opinions on some topic or issue." For Creswell (2016), "Survey research designs are procedures in quantitative research in which investigators administer a survey to a sample or to the entire population of people to describe the attitudes, opinions, behaviors, or characteristics of the population" (p. 376). The design is appropriate for this research as the study attempts to find out the participants' perceptions of the importance of writing skills to Nepalese BBS students.

\section{Instruments}

Two different sets of questionnaires, one for the students and a parallel one for the English teachers, were designed as tools for this purpose. Students' questionnaire focused on areas like (1) the students' profile (2) their EFL writing needs (3) a self -rating of perceived ability. The first part of the questionnaire was generally the collection of various types of biographical data while the second was more personal, relating to the learners' preferences and perception of needs and attempted to record their self-rating of competence in the writing sub-skills (appendix I). Students were asked to rate both the columns meant for 'importance and 'competence' using the five-point Likert scale items (appendix I).

\section{Table 1 Subskills of writing}

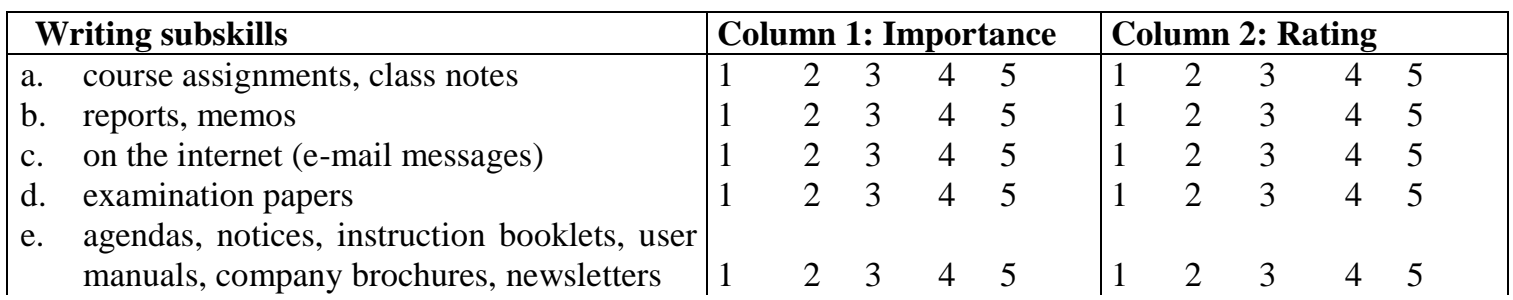




\begin{tabular}{|l|l|lllll|lllll|} 
f. & letters- personal, business etc. (in social / \\
private life) & 1 & 2 & 3 & 4 & 5 \\
g. & diaries, notes/messages & 1 & 2 & 3 & 4 & 5 & 1 & 2 & 3 & 4 & 5 \\
& Others (Please specify and rate) & 1 & 2 & 3 & 4 & 5 \\
1 & 2 & 3 & 4 & 5 & 1 & 2 & 3 & 4 & 5
\end{tabular}

The teacher questionnaire contained the same categories as the student questionnaire, but the item stem was different. The stem for the students was "Rate the importance of learning each of the following for your academic studies while the stem for teachers read as "Rate the importance of learning each of the following for your students' academic studies". Thus teachers' questionnaire was intended to find out (a) the personal details of the participants (b) writing needs of their students and (c) the 'competence' of students in terms of particular sub-skills of writing.

\section{Research Participants}

Ninety-two BBS first-year students of Tribhuvan University, Nepal participated in this study. Out of 92 students, 42 were boys and 50 were girls. The majority of the students were the native of speakers Nepali and were in the age group 18-24 years. Most of the students came from government schools and had studied English at least for eight years. Similarly, the data was also gathered from ten English teachers from four campuses of Kathmandu valley.

\section{RESULTS AND DISCUSSION}

All the responses made by students and teachers were tabulated mainly in the light of the responses they made. Responses made by students and teachers were analyzed, compared, and contrasted in terms of perceived importance and competence.

\section{Students' Perceptions}

In the questionnaire, participants were asked to assess the importance of different seven subskills of writing. They rated on a five-point Likert Scale with the following scales: very important (1), important (2), don't know (3), not very important (4), unimportant or superfluous (5). Similarly, for the second column meant for 'competence' they rated themselves in terms of writing subskills mentioned using a five-point Likert Scale with the following descriptors: very good (1), good (2), don't know (3), not very good (4), poor (5).

\section{Results}

Tables 2 and 3 present the students' perceptions of writing subskills and the results of their self-perceived ability.

\section{Table 2 Students' perceptions of writing subskills}

\begin{tabular}{|c|c|c|c|c|c|c|c|c|c|c|}
\hline \multirow[b]{3}{*}{$\begin{array}{l}\text { Writing } \\
\text { sub-skills }\end{array}$} & \multicolumn{10}{|c|}{ Students' rating of importance of writing subskills } \\
\hline & \multicolumn{8}{|c|}{ Percentages } & \multirow[b]{2}{*}{ mean } & \multirow[b]{2}{*}{ SD } \\
\hline & $\begin{array}{l}\text { V. Im } \\
{[1]}\end{array}$ & $\begin{array}{l}\text { Im } \\
{[2]}\end{array}$ & $\begin{array}{l}\text { DK } \\
{[3]}\end{array}$ & $\begin{array}{l}\text { N V. Im } \\
{[4]}\end{array}$ & $\begin{array}{l}\text { Unim } \\
{[5]}\end{array}$ & $\begin{array}{l}\text { V.Im } \\
\text { Im }\end{array}$ & DK & $\begin{array}{l}\text { N V. Im } \\
\text { + Unim }\end{array}$ & & \\
\hline $\mathrm{a}$ & 69.61 & 24.51 & 2.94 & 2.94 & 0.00 & 94.12 & 2.94 & 2.94 & 1.39 & 0.69 \\
\hline $\mathrm{b}$ & 28.43 & 60.78 & 4.90 & 4.90 & 0.98 & 89.22 & 4.90 & 5.88 & 1.89 & 0.78 \\
\hline $\mathrm{c}$ & 56.86 & 33.33 & 2.94 & 4.90 & 1.96 & 90.20 & 2.94 & 6.86 & 1.62 & 0.91 \\
\hline $\mathrm{d}$ & 73.53 & 23.53 & 1.96 & 0.98 & 0.00 & 97.06 & 1.96 & 0.98 & 1.30 & 0.56 \\
\hline $\mathrm{e}$ & 28.43 & 46.08 & 17.65 & 3.92 & 3.92 & 74.51 & 17.65 & 7.84 & 2.09 & 0.98 \\
\hline $\mathrm{f}$ & 35.29 & 48.04 & 6.86 & 7.84 & 1.96 & 83.33 & 6.86 & 9.80 & 1.93 & 0.95 \\
\hline $\mathrm{g}$ & 27.45 & 47.06 & 12.75 & 12.75 & 0.00 & 74.51 & 12.75 & 12.75 & 2.11 & 0.95 \\
\hline
\end{tabular}


Table 3 Results of self- rating in writing subskills

\begin{tabular}{|c|c|c|c|c|c|c|c|c|c|c|}
\hline \multirow{3}{*}{$\begin{array}{l}\text { Writing } \\
\text { sub-skills }\end{array}$} & \multicolumn{10}{|c|}{ Students' rating of their own competence in subskills of writing } \\
\hline & \multicolumn{8}{|c|}{ Percentages } & \multirow[b]{2}{*}{ mean } & \multirow[b]{2}{*}{ SD } \\
\hline & $\begin{array}{l}\text { VG } \\
{[1]}\end{array}$ & $\begin{array}{l}\text { Good } \\
{[2]}\end{array}$ & $\begin{array}{l}\text { DK } \\
{[3]}\end{array}$ & $\begin{array}{l}\text { N VG } \\
{[4]}\end{array}$ & $\begin{array}{l}\text { Poor } \\
{[5]}\end{array}$ & $\underset{\mathbf{G}}{\mathbf{V}} \mathbf{G}+$ & DK & $\begin{array}{l}\text { N VG + } \\
\text { Poor }\end{array}$ & & \\
\hline $\mathrm{a}$ & 14.71 & 41.18 & 6.86 & 29.41 & 5.88 & 55.88 & 6.86 & 35.29 & 2.65 & 1.20 \\
\hline $\mathrm{b}$ & 4.90 & 39.22 & 12.75 & 39.22 & 3.92 & 44.12 & 12.75 & 43.14 & 2.98 & 1.07 \\
\hline $\mathrm{c}$ & 25.49 & 39.22 & 9.80 & 17.65 & 7.84 & 64.71 & 9.80 & 25.49 & 2.43 & 1.26 \\
\hline $\mathrm{d}$ & 35.29 & 50.00 & 3.92 & 6.86 & 3.92 & 85.29 & 3.92 & 10.78 & 1.94 & 1.01 \\
\hline $\mathrm{e}$ & 3.92 & 10.78 & 28.43 & 35.29 & 21.57 & 14.71 & 28.43 & 56.86 & 3.60 & 1.06 \\
\hline $\mathrm{f}$ & 15.69 & 37.25 & 14.71 & 19.61 & 12.75 & 52.94 & 14.71 & 32.35 & 2.76 & 1.28 \\
\hline $\mathrm{g}$ & 9.80 & 42.16 & 15.69 & 25.49 & 6.86 & 51.96 & 15.69 & 32.35 & 2.77 & 1.14 \\
\hline
\end{tabular}

\section{Discussion}

It can be noticed from the table (2) that there is almost a unanimous consensus (97.06\%) among the respondents that writing examination papers in English (subskill- d) was important for the participants. Similarly, the subskill (a) that is, writing course assignments or class notes $(94.12 \%)$ was another important category in this skill. This was followed by subskills "c" and "b", that is, writing on the internet, e-mail messages (90.20\%), and reports, memos $(89.22 \%)$ respectively. This pattern can be seen in other subskills: e, f, and g. As reflected in the table 2 , an outstanding majority $(74.51 \%)$ of the students opined that writing agendas, notices, instruction booklets user manuals, company brochures and newsletters (subskill e) were important for them. The table projects that it is important for Nepalese BBB students to write agendas, notices, instruction booklets, user manuals, company brochures, and newsletters in English. Writing letters- personal and business letters (subskill f) was found to be important for $83.33 \%$ of the respondents. Similarly, around three-quarters of respondents $(74.51 \%)$ said that writing diaries, notes and messages (subskill g) were important for them.

The table 3 clearly demonstrates that $55.88 \%$ of the respondents said that they were good at writing course assignments, and class notes (subskill a). The overall competence is between good and neutral, i.e. the average mean score for this subskill is 2.65. Similarly, $44.12 \%$ of participants reported that they were good at writing reports and memos (subskill b) while $43.14 \%$ of the total respondents considered themselves as "not very good" at this subskill of writing. $12.75 \%$ of the responses were under the "don't know" category. As reflected in table 3, fairly majority of the informants $(64.71 \%)$ said that they were good at writing on the internet, e-mail messages in English (subskill c). But the overall mean of students' responses is 2.43. It shows their slight inclination towards the "neutral" attitude (scale). Noticeable is $25.49 \%$ of the respondents who chose "not very good" at this skill while rating themselves. A great majority of the respondents $(85.29 \%)$ respondents rated themselves "good" at writing examinations in English (subskill d).

The table projects that the majority of the respondents $(56.86 \%)$ were "not very good" at writing agendas, notices, instruction booklets, user manuals, company brochures, and newsletters (subskill e) in English. The majority of them were either not very good or poor as the mean is 3.60. As the table (3) reflects students' overall competence of writing personal letters, business letters are more or less neutral (mean 2.76, i.e. subskill-f). The mean score (2.77) in ' $\mathrm{g}$ ' suggests that the overall competence is between good and neutral. There is a tilt 
towards 'neutral' at writing diaries, notes/messages in English. About half of the respondents $(51.96 \%)$ said that they were good at writing diaries, notes/messages in English while $35.35 \%$ of the respondents reported that they were not very good at writing diaries, notes/messages. They were students were either "not very good" or "poor."

As seen in the table above all subskills of writing are perceived as 'important'. As is apparent, students' perceived competence is good in 'writing examination papers' while students are almost neutral while rating subskills - writing course assignments, class notes, reports, memos, on the internet, letters, and diaries while participants rated themselves as poor at writing agendas, notices, instruction booklets, user manuals, company brochures, newsletters.

\section{Teachers' Perceptions}

Teachers' questionnaire was intended to find out the writing needs of the student participants and the 'competence' of the students in terms of particular subskills of writing mentioned (appendix II).

Results

Tables 4 and 5 present teachers' perceptions of writing subskills and the results of their rating of students' competence.

Table 4 Teachers' perceptions of writing subskills

\begin{tabular}{|c|c|c|c|c|c|c|c|c|c|}
\hline \multirow[b]{3}{*}{ Writing } & \multicolumn{9}{|c|}{ Teachers' rating of importance of writing subskills } \\
\hline & \multicolumn{8}{|c|}{ Percentages } & \multirow[b]{2}{*}{ mean } \\
\hline & $\begin{array}{l}\text { V. Im } \\
{[1]}\end{array}$ & $\begin{array}{l}\text { Im } \\
{[2]}\end{array}$ & $\begin{array}{l}\text { DK } \\
{[3]}\end{array}$ & $\begin{array}{l}\text { N V. Im } \\
{[4]}\end{array}$ & $\begin{array}{l}\text { Unim } \\
{[5]}\end{array}$ & $\begin{array}{l}\text { V.Im + } \\
\text { Im }\end{array}$ & DK & $\begin{array}{l}\text { N V. Im + } \\
\text { Unim }\end{array}$ & \\
\hline $\mathrm{a}$ & 66.67 & 33.33 & 0.00 & 0.00 & 0.00 & 100.00 & 0.00 & 0.00 & 1.33 \\
\hline $\mathrm{b}$ & 53.33 & 46.67 & 0.00 & 0.00 & 0.00 & 100.00 & 0.00 & 0.00 & 1.47 \\
\hline $\mathrm{c}$ & 53.33 & 40.00 & 6.67 & 0.00 & 0.00 & 93.33 & 6.67 & 0.00 & 1.53 \\
\hline $\mathrm{d}$ & 66.67 & 26.67 & 6.67 & 0.00 & 0.00 & 93.33 & 6.67 & 0.00 & 1.40 \\
\hline $\mathrm{e}$ & 40.00 & 53.33 & 0.00 & 6.67 & 0.00 & 93.33 & 0.00 & 6.67 & 1.73 \\
\hline$f$ & 46.67 & 53.33 & 0.00 & 0.00 & 0.00 & 100.00 & 0.00 & 0.00 & 1.53 \\
\hline $\mathrm{g}$ & 33.33 & 46.67 & 0.00 & 13.33 & 6.67 & 80.00 & 0.00 & 20.00 & 2.13 \\
\hline
\end{tabular}

Table 5 Teachers' rating of their students' writing competence

\begin{tabular}{|c|c|c|c|c|c|c|c|c|c|}
\hline \multirow[b]{3}{*}{ Writing } & \multicolumn{9}{|c|}{ Teachers' rating of their students' competence } \\
\hline & \multicolumn{8}{|c|}{ Percentages } & \multirow[b]{2}{*}{ Mean } \\
\hline & $\begin{array}{l}\text { VG } \\
{[1]}\end{array}$ & $\begin{array}{l}\text { Good } \\
{[2]}\end{array}$ & $\begin{array}{l}\text { DK } \\
{[3]}\end{array}$ & $\begin{array}{l}\text { N VG } \\
{[4]}\end{array}$ & $\begin{array}{l}\text { Poor } \\
{[5]}\end{array}$ & $\underset{\mathbf{G}}{\mathbf{V}} \mathbf{G}+$ & DK & $\begin{array}{l}\text { N VG + } \\
\text { Poor }\end{array}$ & \\
\hline $\mathrm{a}$ & 0.00 & 40.00 & 0.00 & 53.33 & 6.67 & 40.00 & 0.00 & 60.00 & 3.27 \\
\hline $\mathrm{b}$ & 0.00 & 6.67 & 6.67 & 66.67 & 20.00 & 6.67 & 6.67 & 86.67 & 4.00 \\
\hline $\mathrm{c}$ & 0.00 & 20.00 & 13.33 & 46.67 & 20.00 & 20.00 & 13.33 & 66.67 & 3.67 \\
\hline $\mathrm{d}$ & 13.33 & 33.33 & 6.67 & 33.33 & 13.33 & 46.67 & 6.67 & 46.67 & 3.00 \\
\hline e & 0.00 & 6.67 & 6.67 & 46.67 & 40.00 & 6.67 & 6.67 & 86.67 & 4.20 \\
\hline$f$ & 0.00 & 6.67 & 0.00 & 80.00 & 13.33 & 6.67 & 0.00 & 93.33 & 4.00 \\
\hline $\mathrm{g}$ & 0.00 & 6.67 & 6.67 & 40.00 & 46.67 & 6.67 & 6.67 & 86.67 & 4.27 \\
\hline
\end{tabular}

\section{Discussion}

Table 4 presents that all the writing subskills are important for Nepalese BBS students. The mean scores of all responses in each subskill centres round that the category "important". The very interesting picture the table reveals is all informants $(100 \%)$ in "a", "b" and "f" 
admitted that the skills are important. A very low level of uncertainty was expressed by the teachers and very few or almost no responses fall under category "unimportant". It can easily be inferred that these writing subskills are important. An outstanding majority of teachers considered that all other writing subskills are equally important for Nepalese BBS students. The mean scores (between 1.00 and 2.00 on a 5 point scale) show that all writing subskills are important for Nepalese BBS students.

In the subskills (b, e, f, and $\mathrm{g}$ ) as the table 5 shows the mean scores cluster around 4 (not very good) on a five-point scale. Teachers are almost neutral while rating the subskills "a" (mean = 3.27) and "d" (mean = 3.0). The majority of responses $(66.67 \%)$ in "c" come under "poor". Based on results, it can easily be inferred that teachers found their students' abilities in the subskills to be "not very good" or even poor. Based on the percentages of scales and the mean scores, it is evident that students are not good at writing the subskills mentioned.

As shown above the table 4 all the seven subskills of writing aforementioned are equally important for Nepalese BBS students. The mean scores of all responses in each subskill centres round that the category "important". As regards perceived competence, participants did not rate their students as 'good' in any of the subskills. Teachers ranked their students as 'neutral' while rating the subskill- writing 'examination papers' (d). In other writing subskills- writing course assignment, memos, reports, on the internet, agendas, notices . . . letters and diaries, notes/messages ( i.e. a, b, c, e, f \& g ), students were rated as 'not very good or even poor'. Based on results, it can easily be inferred that teachers found their students' competence to be "not very good" or even poor in almost all the subskills. It is evident that students are not good at writing the subskills mentioned.

\section{Comparison of Students' Responses with those of Teachers}

Both the groups perceived all seven subskills of writings 'very important' or 'important' but students found to be "neutral to poor" in these subskills. Teachers indicated that students are almost "not very good" or even "poor" in some cases in the subskills which they considered important. Students rated themselves lower in all the areas which they considered important. Students claimed that they are slightly better than the way their teachers rated them. This is one of the interesting findings of the data.

Table 6 below compares the teachers' perception of the needs and competence of their students with students' perception of needs and their own competence (results of self- rating ability).

\section{Table 6 Comparison of needs and competence}

\begin{tabular}{|l|l|l|l|l|}
\hline \multirow{2}{*}{ Language skill } & \multicolumn{2}{l|}{ Teacher } & \multicolumn{2}{l|}{ Students } \\
\cline { 2 - 5 } & Imp & Comp & Im & Comp \\
\hline Writing Sub-skills & Mean & Mean & Mean & Mean \\
\hline a & 1.33 & 3.27 & 1.39 & 2.65 \\
\hline b & 1.47 & 4.00 & 1.89 & 2.98 \\
\hline c & 1.53 & 3.67 & 1.62 & 2.43 \\
\hline d & 1.40 & 3.00 & 1.30 & 1.94 \\
\hline e & 1.73 & 4.20 & 2.09 & 3.60 \\
\hline f & 1.53 & 4.00 & 1.93 & 2.76 \\
\hline g & 2.13 & 4.27 & 2.11 & 2.77 \\
\hline Avg. & $\mathbf{1 . 5 8}$ & $\mathbf{3 . 7 7}$ & $\mathbf{1 . 7 6}$ & $\mathbf{2 . 7 3}$ \\
\hline
\end{tabular}

Table 6 presents that all subskills of writing are important for Nepalese BBS learners of English. Overall average values of all subskills for column, i.e. 'importance' obtained from 
both the groups fall between 1 and 2 on a scale 5. Averages of all average values for the first column as rated by both groups of participants i.e. teachers and students are 1.58 and 1.76 respectively. It is evident from the table that there is consistency between students' perceptions of these subskills and teachers' perceptions of the needs of those subskills. That is, the results confirm that there is a close relationship between the way teachers responded to the questionnaires and students reported.

As is apparent from table 6, teachers rated their students between 'neutral' and 'not very good', (i.e., 3.77). But slight tilt toward the scale 'not very good' can easily be observed. For instance, in subskill "a" students ranked themselves at 2.65 while teachers rated them at 3.27. The same is true for other subskills. On the other hand, it can be seen from the table that students rated themselves between 'good' and 'neutral'(i.e., 2.73).

So, all the language skills and their subskills aforementioned are equally important. The subskills which both groups considered as 'important' or 'very important' can be summed up as follows:
a. course assignments, class notes
b. reports, memos
c. on the internet, e-mail messages
d. examination papers
e. agendas, notices, instruction booklets, user manuals, company brochures, newsletters
f. letters- personal, business, etc. (in social / private life)
g. diaries, notes/messages

Results of rating for the second column, i.e. competence as perceived by the participants vary. The average of all average values for this column falls between 3 and 4 on a scale of 5 when rated by the teacher participants and falls between 2 and 3 when rated by the student participants.

Both the groups of participants perceived all 8 subskills of writing as 'important.' Students rated themselves between 'good' and 'neutral' i.e. at 2.73 (Avg.) on a 5 point scale while teacher participants ranked them between 'neutral and 'not very good' i.e. at 3.77 (Avg.) on a 5 point scale.

\section{CONCLUSION}

Writing has now become a part of the scholarship. Individuals are required to gain fluency in the conventions of writing in English to understand their disciplines. Writing helps individuals to establish their careers and to successfully navigate their learning. It involves writing emails, commercial letters, reports, notes, notices, memos, messages, instruction booklets, diaries, agendas, minutes of meetings, etc. These skills are a part of modern academic and corporate life. This study aimed at investigating ESP writing needs of Nepalese BBS students. It sought to answer following the questions: What subskills of writing do they need to develop to navigate their learning? How do teachers and students perceive writing? The study found that both the group of participants (teachers and students) considered all seven subskills of writing as important. The subskills which both the groups of participants perceived important were: a) Writing course assignments, class notes b) Writing reports, memosc) Writing on the internet, e-mail messages d) Writing examination papers) Writing agendas, notices, instruction booklets, usermanuals, company brochures, newsletters f) Writing letters- personal, business, etc. (in social / private life) and g) Writing diaries,notes/messages. Regarding competence, student participants rated themselves between 'good' and 'neutral' i.e. at 2.73 (Avg.) on a 5 point scale while teacher participants ranked them between 'neutral and 'not very good' i.e. at 3.77 (Avg.) on a 5 point scale. This implies that teachers' rating of their students' competence inclines slightly towards scale 'not very good'. The subskills of writing in which teacher participants rated them poor were: writing 
reports, memos, agendas, notices, instruction booklets, user manuals, company brochures, letters and diaries, and messages. The findings indicated that students need to develop all the seven subskills of writing mentioned, and teachers are required to help them learn these subskills of writing.

\section{REFERENCES}

Bacha, N.N., \& Bahous, R. (2008). Contrasting views of business students' writing needs in an EFL environment. English for Specific Purposes, 27, 74-93.

Bernhardt, S. A. (1985). Writing across the curriculum at one university: A survey of faculty members and students. ADE Bulletin, 082, 55-59.

Berwick, R. (1989). Needs assessment in language programming: From theory to practice. In R. K. Johnson (Ed.), The second language curriculum (pp. 48-62). Cambridge: Cambridge University Press.

Brindley, G. (1989). The role of needs analysis in adult ESL program design. In R. K. Johnson (Ed.), The second language curriculum (pp. 63-78). Cambridge: Cambridge University Press.

Campbell, N. (2002). Getting rid of the yawn factor: Using a portfolio assignment to motivate students in professional writing class (My Favorite Assignment). Business Communication Quarterly, 65(3), 42-54.

Chambers, F. (1980). A re-evaluation of needs analysis in ESP. ESP Journal,1(1), 25-33.

Chowdhury, T. A. (2020). Towards consistent and fair assessment practice of students' subjective writing. International Journal of Linguistics and Translation Studies, 1(1), 32-41. https://doi.org/10.36892/ijlts.v1i1.14.

Creswell, J.W. (2016). Educational research: Planning, conducting, and evaluating quantitative and qualitative research. Boston: Pearson.

Dudley Evans, T., \& St John, M. J. (2003). Developments in English for specificpurposes: A multidisciplinary approach. Cambridge: Cambridge University Press.

Finney, D. (2002). The ELT curriculum: A flexible model for a changing world. In J. C. Richards \& W. A. Renandya (Eds.), Methodology in language teaching: An anthology of current practice (pp. 69-79). Cambridge: Cambridge University Press.

Gay. L.R., Mills, G.E., \& Airasian, P.W. (2017). Educational research. New Delhi: Pearson Education Limited.

Graham, S., Harris, K. R., \& Mason, L. (2005). Improving the writing performance, knowledge, and selfefficacy of struggling young writers: The effects of self-regulated strategy development. Contemporary Educational Psychology, 30(2), 207-241.

Grier, A.S. (2005). Integrating needs assessment into career and technical curriculum development. Journal of Industrial Teacher Education, 42 (1), 59-66.

Hutchinson, T., \& Waters, A. (1987). English for specific purposes: A learning centred approach. Cambridge: Cambridge University Press.

Hyland, K (2013). ESP and Writing. In B. Paltridge \& S. Starfield (Eds.), The Handbook of English for Specific Purposes (pp. 95-114). West Sussex, UK: John Wiley \& Sons, Inc.

Hyland, K. (2002). Specificity revisited: How far should we go now? English for Specific Purposes21(4), 385-395

Johns, A. (1990). English for specific purposes: Its history and contribution. In Celce-Murcia, M. (Ed), Teaching English as a second or foreign language (pp. 67-77). Boston, MA: Heinle \& Heinle. 
Johns, A.M., \& Dudley-Evans, T.(1991). English for specific purposes: International in scope. TESOL Quarterly, 25(2), 297-314.

Jordan, R, R. (1997). English for academic purposes: A guide and resource book for teachers. Cambridge, CB2: Cambridge University Press.

Long, M. H. (2005). Methodological issues in learner needs analysis. In M. H. Long (Ed.), Second language needs analysis (pp. 19-76). Cambridge: Cambridge University Press.

Munby, J. (1978). Communicative syllabus design. Cambridge: Cambridge University Press.

OWL. (2003). Writing across the curriculum and writing in the disciplines. The Online Writing Lab, West Lafayette: IN, Purdue University.

Räisänen, C., \& Fortanet-Gómez, I. (2008). The state of ESP teaching and learning in Western European higher education after Bologna. In I. Fortanet-Gómez \& C. A. Räisänen (Ed.), ESP in European higher education (pp.11-58). John Benjamins Publishing Company: Amsterdam.

Richards, J. C. (2001). Curriculum development in language teaching. Cambridge: Cambridge University Press.

Richterich, R. (1973/1980). Definition of language needs and types of adults. In J. Trimm, R. Richterich, J. Van Ek, \& D. Wilkins (Eds.), Systems development in adult language learning (pp. 29-88). Strasbourg: Council of Europe/ Oxford: Pergamon.

Richterich, R., \& Chancerel, J. L. (1977). Identifying the needs of adults learning a foreign language. Strasbourg: Council of Europe/Oxford: Pergamon.

Robinson, P. (1991). ESP today: A practitioner's guide. New York: Prentice Hall.

Schott Karr, S. (2001). Learning business writing online. Financial Executive, 17(i4), 64<http://web1infotracgalgroup.com/itw/informark/647/660/55167691w1/purl=r>.

Seedhouse, P. (1995). Needs analysis and the general English classroom. ELT Journal, 49 (1), 59-65.

Song, B. (2006). Content-based ESL instruction: Long-term effects and outcomes. English for Specific Purposes, 25(4), 420-437.

Strevens, P. (1977). Special purpose language learning: A perspective. Language Teaching and Linguistics Abstracts, 10, 145-163.

Strevens, P. (1988). ESP after twenty years: A re-appraisal. In M. Tickoo (Ed.), ESP: State of the art (pp. 1-13). Singapore: SEAMEO Regional Language Centre.

West, R. (1994). Needs analysis in language teaching. Language Teaching, 27 (1), 1-19. doi:10.1017/S0261444800007527

West, R. (1997). Needs analysis: State of the Art. In R. Howard, \& G. Brown, (Eds.), Teacher education for LSP (pp. 68-79). Clevedon, UK: Multilingual Matters.

\section{$\underline{\text { AUTHOR'S BIO }}$}

Dr. Gopal Prasad Pandey is Reader in English Education at Tribhuvan University (TU), Kathmandu, Nepal where he has been teaching ELT and Applied linguistics courses for two decades now. Dr. Pandey is currently the Chairperson of the Department of English Education, University Campus, TU. His interest areas include critical discourse analysis, ESP studies, syllabus design, materials production, teacher professional development. 


\section{APPENDICES}

\section{Appendix I: Questionnaire for Students}

Name :

Address :

Age :

First language:

Name of the campus:

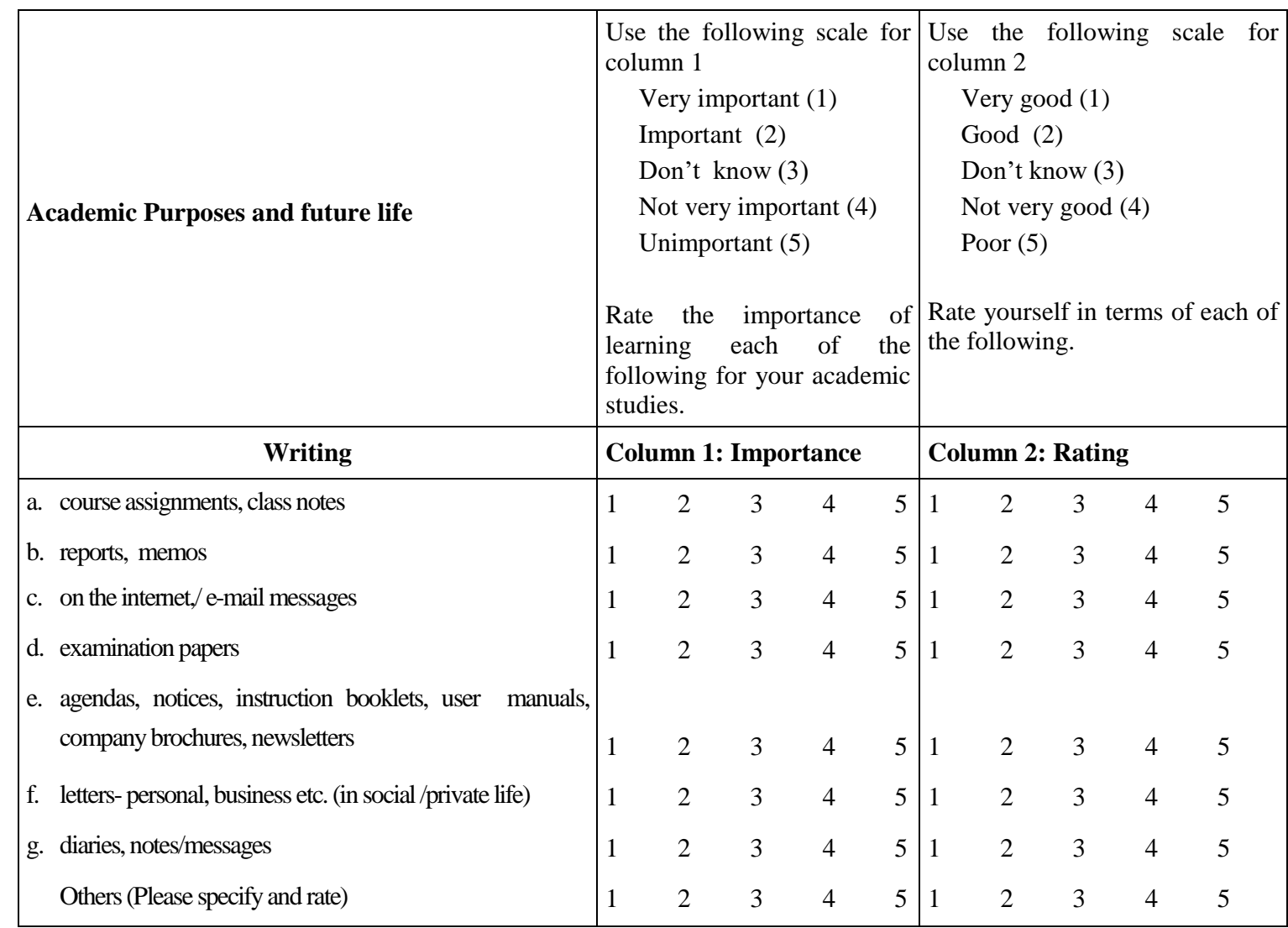




\section{Appendix II: Questionnaire for Teachers}

Name (optional):

Address:

Nationality:

Experience:

First language:

Name of the campus:
Designation:

Age /Sex:

Educational Qualification:

TEFL courses/ training:

Other languages:

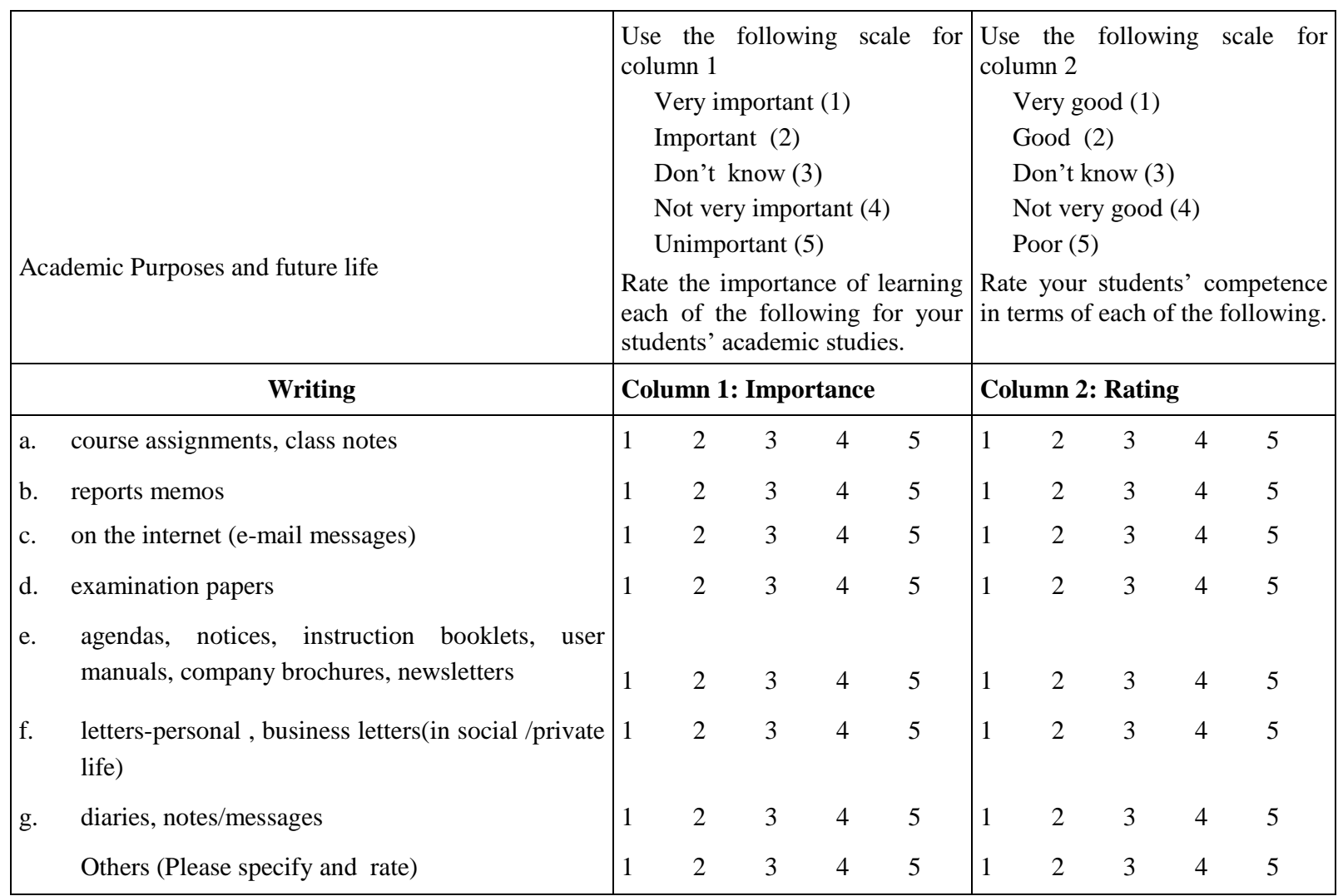

